\title{
EFFECTIVENESS OF SELECTED ENTOMOPATHOGENIC FUNGI IN PACKED RICE GRAIN AT ROOM TEMPERATURE AGAINST CORCYRA CEPHALONICA STAINTON
}

\author{
Hendrawan Samodra \\ Agricultural Quarantine Agency, Ministry of Agriculture, \\ JL. Harsono RM No. 3 Gd. E Lt. V, Ragunan, Jakarta Selatan 12550, Indonesia \\ Yusof Bin Ibrahim* \\ Department of Plant Protection, Faculty of Agriculture, \\ Universiti Putra Malaysia, Serdang 43400, Selangor, Malaysia
}

Received 26 September 2005

\begin{abstract}
Eight isolates of entomopathogenic fungi were evaluated as dried conidia against the rice moth, Corcyra cephalonica. In bioassays two isolates of Beauveria bassiana (BbGc and BbPs) and one isolate of Metarhizium anisopliae (MaPs) consistently gave high mortality to $C$. cephalonica larvae. Formulations in either kaolin, talc or tapioca flour $(20 \% \mathrm{w} / \mathrm{w}$ a.i. $)$ thoroughly mixed with long grain rice in plastic cups $(8 \mathrm{~cm}$ diameter by $5 \mathrm{~cm})$ gave complete larval mortality by the $12^{\text {th }}$ day of treatment. However, in general those formulated in kaolin and talc were more efficacious and faster to kill compared to those formulated in tapioca flour or the unformulated control. Even at the lowest rate of $0.05 \mathrm{~g}$ BbGc in kaolin provided $100 \%$ mortality 7 days after introduction compared with other dust formulations. Isolate BbGc in kaolin and talc administered at $0.4 \mathrm{~g}$ a.i. in $200 \mathrm{~g}$ rice packed in plastic kept at room temperature provided protection against the rice moth up to 4 months of storage. Larval mortality in excess of $90 \%$ was obtained 15 days after introduction. Formulations of MaPs was effective only within the first month of storage beyond which infectivity rapidly declined.
\end{abstract}

Keywords: entomopathogenic fungi, dust formulation, rice moth, storage

\section{INTRODUCTION}

The rice moth, Corcyra cephalonica Stn. is believed to be of eastern origin but has become a cosmopolitan species. It has spread through out the world with the transport of food and animal feeds. Beside rice, the rice moth is also a major pest of stored grains of pearl millet and sorghum. Rice packed in plastics are also known to get infested together with the rice weevils. It becomes established more readily in stored grains that are broken or seeds that have been damaged. For this reason the species is regarded as a secondary pest [10]. The larvae spin in the flour and broken seeds, silken tube in which it lives, and also spin fine threads wherever they crawl. Considerable amount of silk is produced until they become full grown. The broken seeds

\footnotetext{
*Corresponding author e-mail: yusofib@agri.upm.edu.my
} 
have always been found to provide a more suitable medium than either whole seeds or flours. However, the favourability of whole seeds in comparison with flours depends upon the commodity under consideration. Its development in rice is both more rapid and successful on whole grains than on the flour.

Control has been primarily through the use of gaseous fumigants such as methyl bromide and pelletised phosphine and residual insecticides to augment the more obvious approach of hygiene $[1,9]$. However, fumigation has many limitations among which the lack of penetration in sufficient concentration, undesirable residues and potential fire hazard [12]. In Malaysia methyl bromide is under threat of restricted use and possible withdrawal because it apparently depletes the ozone layer of the earth's atmosphere; the EPA (2001) has proposed elimination of this compound by 2005. The excessive use of conventional insecticides has resulted in a number of serious problems, among which is resistance to the insecticides, leading to a higher cost of crop production [11].

The use of entomopathogenic fungi is a novel approach for controlling insect pests of stored grains. Rice (1999) reported an isolate of Beauveria bassiana (Balsamo) Vuillemin to be pathogenic to adults of Sitophilus oryzae, Rhyzopertha dominica (F.) and Tribolium castaneum (Herbst). A soil isolate of $B$. bassiana was also reported to be effective against adults of Oryzaephilus surinamensis (L.) [16]. Beauveria bassiana has also shown a considerable potential for the control of the larger grain borer, Prostephanus truncatus (Horn) of maize and cassava [15]. The other entomopathogenic fungus, Metarhizium anisopliae (Metsch.) Sorokin was found to infect the groundnut bruchid Carydon serratus (Olivier) [4]. Mycoinsecticides have been shown to have considerable potential in insect pest management worldwide. However, their use as microbial control agents on stored grain insects has received little attention [2]. In this paper, we report on the effectiveness of selected entomopathogenic fungal isolates against the rice moth, Corcyra cephalonica Stn..

\section{MATERIALS AND METHODS}

\subsection{Culture of insect}

Plastic containers $(40 \times 30 \times 20 \mathrm{~cm})$ capped with muslin cloths were used to mass rear $C$. cephalonica on $50 \% \mathrm{w} / \mathrm{w}$ mixture of rice and maize [13] in an ambient environment of $28 \pm 2^{\circ} \mathrm{C}$ and 60 - 95\% RH. This medium was cleaned and sterilised in an autoclave for $30 \mathrm{~min}$ and stored in the freezer prior to use. All utensils used were thoroughly cleaned and disinfected by storing in the oven. To obtain larvae of standardised age for treatment, 20 pairs of adults were placed in oviposition jars overnight and the eggs were collected the following morning. Only larvae of three and four weeks old were used in all treatments.

\subsection{Production of dry conidia}

The original hosts and countries of origin for the fungal isolates used in this study are listed in Table 1. These isolates were selected because they gave good sporulation as indicated by their full plate production of conidia on PDA. Conidia singlely isolated from reinfected cadaver of $C$. cephalonica larva were maintained at a room temperature of $28 \pm 2^{\circ} \mathrm{C}$ on PDA which had been sterilised for $20 \mathrm{~min}$ at $121^{\circ} \mathrm{C}$ and a pressure of $1.05 \mathrm{~kg} / \mathrm{cm}^{2}$. These isolates were then used for the production of air-dried conidia in rice medium; only conidia from $15 \mathrm{~d}$ old sporulating cultures were transferred to the rice medium. The culture medium was consisted of $200 \mathrm{~g}$ whole grain rice ( $10 \%$ broken; $80 \% \mathrm{w} / \mathrm{v}$ distilled water) in a polyethylene bag sterilised in an autoclave for $30 \mathrm{~min}$ at $121^{\circ} \mathrm{C}$ at a pressure of $1.05 \mathrm{~kg} / \mathrm{cm}^{2}$. The bags were loosely sealed with cotton plug in a PVC pipe (3 cm diameter) during autoclaving. After a $24 \mathrm{~h}$ cooling period, each bag was inoculated with $5 \mathrm{ml}$ of the respective conidial suspension $\left(1 \times 10^{9}\right.$ conidia $\left.\mathrm{ml}^{-1}\right)$ using a 
micropipette and replugged with cotton. The bags were shaken vigorously every $24 \mathrm{~h}$ for $3 \mathrm{~d}$ to distribute the inoculum evenly during incubation at $28 \pm 2^{\circ} \mathrm{C}$ in the dark for 15 days. After incubation, the colonised substrate was then spread evenly, sandwiched between paper towels to further encourage sporulation and air-dried for $5-7 \mathrm{~d}$ in the laboratory. The dried conidia were then harvested by sieving through $125 \mu \mathrm{m}$ particle size following the method of Daoust et al. [3] and Belloa et al. [2].

Table 1: Origin of fungal isolates

\begin{tabular}{|c|c|c|c|}
\hline Species & Code & Insect host & Location \\
\hline \multirow[t]{3}{*}{$\begin{array}{l}\text { Beauveria } \\
\text { bassiana }\end{array}$} & BbGc & $\begin{array}{l}\text { Glenea celia } \\
\text { (Cerambycidae; larva) }\end{array}$ & $\begin{array}{l}\text { Malaysia (Tuaran, } \\
\text { Sabah) }\end{array}$ \\
\hline & BbPs & $\begin{array}{l}\text { Phyllotreta striolata } \\
\text { (Chrysomelidae; adult) }\end{array}$ & $\begin{array}{l}\text { Malaysia (Serdang, } \\
\text { Selangor) }\end{array}$ \\
\hline & BbPc & $\begin{array}{l}\text { Phyllotreta cruciferae } \\
\text { (Chrysomelidae; adult) }\end{array}$ & $\begin{array}{l}\text { Malaysia (Serdang, } \\
\text { Selangor) }\end{array}$ \\
\hline \multirow[t]{5}{*}{$\begin{array}{l}\text { Metarhizium } \\
\text { anisopliae }\end{array}$} & MaPs & $\begin{array}{l}\text { Phyllotreta striolata } \\
\text { (Chrysomelidae; adult) }\end{array}$ & $\begin{array}{l}\text { Malaysia (Serdang, } \\
\text { Selangor) }\end{array}$ \\
\hline & MaORMaj & $\begin{array}{l}\text { Oryctes rhinoceros } \\
\text { (Scarabaeidae; larva) }\end{array}$ & $\begin{array}{l}\text { Malaysia (Bukit } \\
\text { Raja, Selangor) }\end{array}$ \\
\hline & MaORMan & $\begin{array}{l}\text { Oryctes rhinoceros } \\
\text { (Scarabaeidae; larva) }\end{array}$ & $\begin{array}{l}\text { Malaysia (Bukit } \\
\text { Raja, Selangor) }\end{array}$ \\
\hline & MaGmC & $\begin{array}{l}\text { Galleria melonella } \\
\text { (Pyralidae; larva) }\end{array}$ & $\begin{array}{l}\text { Indonesia (Cilacap, } \\
\text { Java) }\end{array}$ \\
\hline & MaSc & $\begin{array}{l}\text { Scotinophara coarctata } \\
\text { (Pentatomidae; nymph) }\end{array}$ & $\begin{array}{l}\text { Indonesia (Bogor, } \\
\text { Java) }\end{array}$ \\
\hline
\end{tabular}

\subsection{Test for pathogenicity}

The conidial concentrations were prepared from an initial stock of $1 \times 10^{9}$ conidia $\mathrm{g}^{-1}$, as determined using a Neubauer haemocytometer, and diluted with tapioca flour (as carrier) to $1 \times$

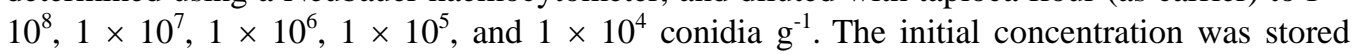
overnight in the refrigerator at $4^{\circ} \mathrm{C}$ prior to use. Twenty C. cephalonica larvae were placed in a $9 \mathrm{~cm}$ Petri dish containing $0.1 \mathrm{~g}$ of the respective conidial mixture. The control consisted of the carrier only. Each treatment was replicated 5 times. After $24 \mathrm{~h}$ the insects were transferred to a clean Petri dish with only rice grains as food. Thereafter, mortality was recorded everyday for 15 days. Dead insects were removed and confirmed for fungal infection. Only those insects that showed symptoms of fungal infection as manifested by sporulation of the fungus breaking through the cuticle were counted as a kill by the pathogen. The test was also repeated on the eggs; fifty $24 \mathrm{~h}$ old eggs were used per treatment. The final proportions of dead insects were analysed by probit analysis (S103, Statistical Research Service, Canada DOA, unpublished) based on Finney [6].

\subsection{Effectiveness of conidial formulations in rice grain}

Long grain rice (5\% broken; $14 \%$ M.C.) was used in this study. The carriers were kaolin, talc and tapioca flour. Three most virulent isolates determined earlier from pathogenicity tests were used in this study. Formulations were prepared by mixing $20 \% \mathrm{w} / \mathrm{w}$ a.i. consisted of dried conidia with kaolin, talc or tapioca flour. The powdered formulation was applied at a dosage of 
$0.05,0.10$ and $0.15 \mathrm{~g}$ a.i. to $50 \mathrm{~g}$ rice grain in a plastic cup. Twenty 3 - 4 week old larvae were placed in each cup $(8 \mathrm{~cm}$ diameter by $5 \mathrm{~cm}) 1 \mathrm{~d}$ after applying the respective treatments. The treatments were replicated 4 times with an unformulated control. The experiment was run for 15 $\mathrm{d}$ with the mortality checked daily. Mortalities were analysed using one-way ANOVA and the means were compared using least significant difference (LSD). The data were transformed arcsine square-root of the percent mortality of the initial number [7].

\subsection{Persistency of virulence upon storage in packed rice}

An amount of $0.4 \mathrm{~g}$ a.i. of B. bassiana and M. anisopliae formulated in kaolin, tapioca flour, talc and unformulated control were applied on 200 g rice grain (14\% M.C.) packed in plastic. Twenty-five larvae were then introduced into each bag which had been stored at room temperature $\left(28 \pm 2^{\circ} \mathrm{C}\right)$ and $60 \pm 10 \% \mathrm{RH}$ for $1,2,3,4$, and 6 months. The treatments were replicated 4 times. Percentage of larvae infected were recorded 4, 8, 12 and $15 \mathrm{~d}$ after introduction. The mortality responses were analysed using one-way ANOVA and the means were compared using least significant difference (LSD).

\section{RESULTS AND DISCUSSION}

\subsection{Test for pathogenicity}

Table 2 shows isolates BbGc, BbPs and MaPs were the three best isolates consistently giving high mortalities compared with the other isolates. It was apparent that $50 \%$ mortality was reached in less than four days and by the $7^{\text {th }}$ day of exposure to $1 \times 10^{8}$ conidia $\mathrm{g}^{-1}$ only these three isolates reached mortality level in excess of $80 \%$ (Fig. 1). The median effective concentration $\left(\mathrm{EC}_{50}\right)$ for these isolates against the larvae were $1.238 \times 10^{6}(\mathrm{BbGc}), 2.072 \times 10^{6}$ (BbPs) and $1.775 \times 10^{6}$ (MaPs) conidia $\mathrm{g}^{-1}$ respectively (Table 3$)$. These three isolates were selected for subsequent experiments.

Table 2: Mean percent larval mortality of Corcyra cephalonica upon exposure to selected entomopathogenic fungal isolates 15 days after treatment

\begin{tabular}{lllllll}
\hline \multirow{2}{*}{ Isolates } & \multicolumn{7}{c}{ Concentrations } \\
\cline { 2 - 6 } & $10^{9}$ & $10^{8}$ & $10^{7}$ & $10^{6}$ & $10^{5}$ & $10^{4}$ \\
\hline BbGc & $100 \mathrm{a}$ & $100 \mathrm{a}$ & $80 \mathrm{a}$ & $43 \mathrm{a}$ & $17 \mathrm{a}$ & $0 \mathrm{a}$ \\
BbPs & $100 \mathrm{a}$ & $98 \mathrm{a}$ & $73 \mathrm{a}$ & $35 \mathrm{ab}$ & $13 \mathrm{a}$ & $0 \mathrm{a}$ \\
BbPc & $100 \mathrm{a}$ & $85 \mathrm{~b}$ & $51 \mathrm{~b}$ & $30 \mathrm{~b}$ & $12 \mathrm{a}$ & $2 \mathrm{a}$ \\
MaPs & $100 \mathrm{a}$ & $98 \mathrm{a}$ & $72 \mathrm{a}$ & $37 \mathrm{ab}$ & $15 \mathrm{a}$ & $2 \mathrm{a}$ \\
MaORMan & $100 \mathrm{a}$ & $73 \mathrm{bc}$ & $36 \mathrm{c}$ & $15 \mathrm{c}$ & $2 \mathrm{~b}$ & $0 \mathrm{a}$ \\
MaORMaj & $97 \mathrm{a}$ & $63 \mathrm{c}$ & $32 \mathrm{c}$ & $15 \mathrm{c}$ & $3 \mathrm{~b}$ & $0 \mathrm{a}$ \\
MaSc & $97 \mathrm{a}$ & $64 \mathrm{c}$ & $35 \mathrm{c}$ & $17 \mathrm{c}$ & $9 \mathrm{a}$ & $0 \mathrm{a}$ \\
MaGmC & $84 \mathrm{~b}$ & $35 \mathrm{~d}$ & $15 \mathrm{~d}$ & $5 \mathrm{~d}$ & $0 \mathrm{~b}$ & $0 \mathrm{a}$ \\
\hline
\end{tabular}

Means within column followed by the same letter are not significantly different at $p=0.05$ according to least significant difference (LSD). Control = zero mortality. 


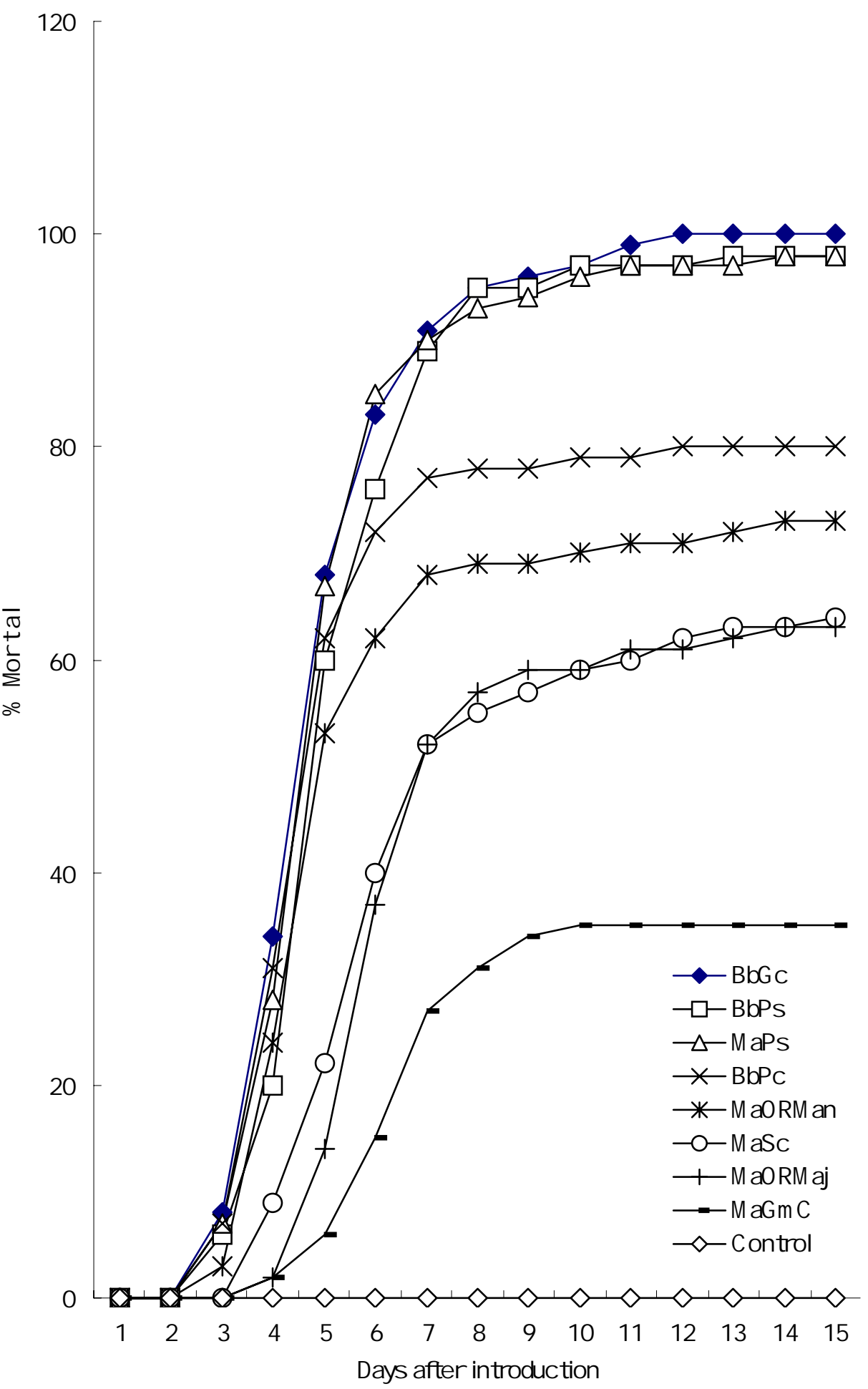

Fig. 1: Mean percent cumulative mortality of $C$. cephalonica larvae upon exposure to eight entomopathogenic fungal isolates at concentration $1 \times 10^{8}$ conidia $g^{-1}$ observed for 15 days after introduction 
Table 3: Effective concentrations of selected entomopathogenic fungal isolates against Corcyra cephalonica larvae

\begin{tabular}{|c|c|c|c|c|c|c|c|}
\hline Isolate & $\begin{array}{l}\text { A } \\
\text { (intercept) }\end{array}$ & $\begin{array}{l}b \pm S E \\
\text { (slope) }\end{array}$ & $\mathrm{X}^{2}$ & $\mathrm{EC}_{50}$ & 95\%FL & $\mathbf{E C}_{95}$ & 95\%FL \\
\hline $\mathrm{BbGc}$ & 71 & $1.097 \pm 0.079$ & 1.747 & $238 \times 10^{6}$ & $\begin{array}{l}8.916 \times 10^{5} \\
-1.719 \times 10^{6}\end{array}$ & $4.149 \times 10^{7}$ & $\begin{array}{r}2.425 \times 10^{7} \\
-8.224 \times 10^{7}\end{array}$ \\
\hline $\mathrm{BbPs}$ & 893 & $1.091 \pm 0.074$ & 3.447 & $2.072 \times 10^{6}$ & $\begin{array}{l}1.506 \times 10^{6} \\
-2.855 \times 10^{6}\end{array}$ & $6.669 \times 10^{7}$ & $\begin{array}{l}4.007 \times 10^{7} \\
-1.260 \times 10^{8}\end{array}$ \\
\hline $\mathrm{BbPc}$ & 0.109 & $0.724 \pm 0.058$ & 2.468 & $5.658 \times 10^{6}$ & $\begin{array}{l}3.691 \times 10^{6} \\
-8.991 \times 10^{6}\end{array}$ & $1.057 \times 10^{9}$ & $\begin{array}{l}4.303 \times 10^{8} \\
-3.512 \times 10^{9}\end{array}$ \\
\hline MaPs & -0.850 & $0.936 \pm 0.062$ & 4.125 & $1.775 \times 10^{6}$ & $\begin{array}{l}1.246 \times 10^{6} \\
-2.541 \times 10^{6}\end{array}$ & $1.016 \times 10^{8}$ & $\begin{array}{l}5.501 \times 10^{7} \\
-2.226 \times 10^{8}\end{array}$ \\
\hline MaORMan & -1.337 & 0.86 & 0.687 & & $\begin{array}{l}1.398 \times 10^{7} \\
-3.366 \times 10^{7}\end{array}$ & & $\begin{array}{l}6.946 \times 10^{8} \\
-5.703 \times 10^{9}\end{array}$ \\
\hline MaORMaj & -0.551 & $0.735 \pm 0.071$ & 0.439 & $3.605 \times 10^{9}$ & $\begin{array}{c}2.187 \times 10^{7} \\
-1.977 \times 10^{9}\end{array}$ & $6.262 \times 10^{9}$ & $\begin{array}{l}1.977 \times 10^{9} \\
-3.287 \times 10^{10}\end{array}$ \\
\hline MaSc & 0.272 & $0.631 \pm 0.061$ & 0.913 & $3.077 \times 10^{7}$ & $\begin{array}{l}1.764 \times 10^{7} \\
-6.144 \times 10^{7}\end{array}$ & $1.241 \times 10^{10}$ & $\begin{array}{l}3.293 \times 10^{9} \\
-8.357 \times 10^{10}\end{array}$ \\
\hline MaGmC & -1.022 & $0.708 \pm 0.099$ & 1.199 & $3.183 \times 10^{8}$ & $\begin{array}{l}1.413 \times 10^{8} \\
-1.159 \times 10^{9}\end{array}$ & $6.696 \times 10^{10}$ & $\begin{array}{l}1.047 \times 10^{10} \\
-1.659 \times 10^{12}\end{array}$ \\
\hline
\end{tabular}

20 larvae per replicate, 5 replicate per dosage, 7 dosages per assay $(N=700)$

Table 4: Mean percent larval mortality of Corcyra cephalonica upon exposure to dust formulations of selected entomopathogenic fungal isolates in $50 \mathrm{~g}$ rice grains seven days after treatment

\begin{tabular}{llccc}
\hline \multirow{2}{*}{ Fungi } & Carrier & \multicolumn{3}{c}{ Dosages (g a.i.) } \\
\cline { 3 - 5 } & & 0.05 & 0.10 & 0.15 \\
\hline \multirow{2}{*}{ B. bassiana (BbGc) } & Kaolin & $100.0 \mathrm{a}$ & $100.0 \mathrm{a}$ & $100.0 \mathrm{a}$ \\
& Talc & $95.0 \mathrm{~b}$ & $97.5 \mathrm{~b}$ & $97.5 \mathrm{ab}$ \\
& Tapioca Flourr & $91.2 \mathrm{~b}$ & $92.5 \mathrm{c}$ & $96.3 \mathrm{~b}$ \\
& Unformulated & $92.0 \mathrm{~b}$ & $96.4 \mathrm{~b}$ & $95.0 \mathrm{~b}$ \\
\hline \multirow{2}{*}{ B. bassiana (BbPs) } & Kaolin & $96.3 \mathrm{a}$ & $97.5 \mathrm{a}$ & $100.0 \mathrm{a}$ \\
& Talc & $90.0 \mathrm{~b}$ & $93.8 \mathrm{ab}$ & $96.3 \mathrm{~b}$ \\
& Tapioca Flour & $72.5 \mathrm{c}$ & $81.3 \mathrm{c}$ & $87.5 \mathrm{c}$ \\
& Unformulated & $67.5 \mathrm{c}$ & $88.3 \mathrm{bc}$ & $91.3 \mathrm{c}$ \\
\hline \multirow{2}{*}{ M. anisopliae (MaPs) } & Kaolin & $87.5 \mathrm{~b}$ & $96.3 \mathrm{a}$ & $100.0 \mathrm{a}$ \\
& Talc & $96.3 \mathrm{a}$ & $96.3 \mathrm{a}$ & $100.0 \mathrm{a}$ \\
& Tapioca Flour & $81.3 \mathrm{~b}$ & $90.0 \mathrm{~b}$ & $97.5 \mathrm{a}$ \\
& Unformulatedr & $78.8 \mathrm{~b}$ & $91.3 \mathrm{~b}$ & $95.0 \mathrm{~b}$ \\
\hline
\end{tabular}

Means within column for each fungus followed by the same letter are not significantly different at $p=0.05$ according to least significant difference (LSD). 

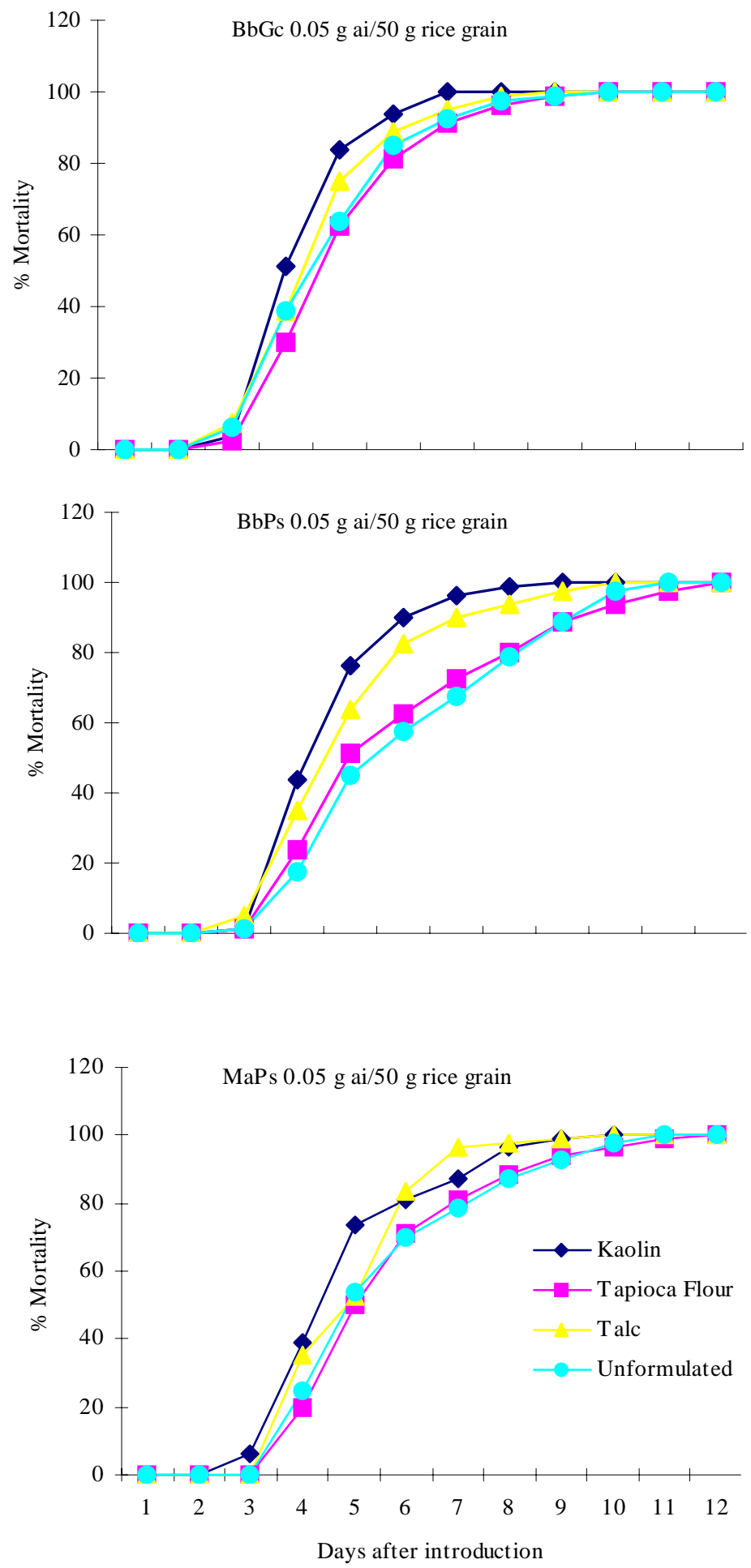

Fig. 2: Comparative mean percent larval mortality of C. cephalonica upon exposure to conidial formulation of three entomopathogenic fungal isolates 


\subsection{Effectiveness of conidial formulations in rice grain}

The larval mortalities of $C$. cephalonica upon exposure to various formulations of the selected fungal isolates with kaolin, talc or tapioca flour are shown in Table 4. Isolate BbGc formulated in kaolin was significantly the most superior and gave $100 \%$ mortality $7 \mathrm{~d}$ after introduction compared with the other formulations. Apparently, the trend was similar with isolate BbPs, while formulations with kaolin was as effective as talc for isolate MaPs with mortalities recorded in excess of $90 \%$ (Fig. 2). Based on carrier types and classification of inertness, particles of kaolin which are derived from inorganic silicate [17] are harder than the tapioca flour which is an organic botanical. It was observed that when the larva crawls in the rice grains the waxy larval cuticle became abraded by this carrier. It is thus suggested that the abrasive activity by kaolin facilitates the penetration of conidial germ tube through the insect`s integument and hence leads to enhanced infection.

\subsection{Persistency of virulence upon storage in packed rice}

Table 5 shows that all the dust formulations and unformulated control of $B$. bassiana in the rice grains stored for 3 months at room temperature still provided $100 \%$ mortality to C. cephalonica larvae. Isolates of BbGc and BbPs formulated in kaolin and BbPs formulated in tapioca flour gave $100 \%$ larval mortality by the $15^{\text {th }}$ day of introduction. Even those that had been stored for 4 months still provided effective control in excess of $90 \%$. The pathogenicity of $M$. anisopliae against $C$. cephalonica larvae decreased rapidly upon storage at room temperature affording less than $60 \%$ control by the second month of storage; the unformulated control was significantly the least effective. All MaPs treatments were less than $50 \%$ effective by the third month of storage. A marked decrease in larval mortality was recorded after 6 months of storage; mean percent larval mortality against isolates BbGc and BbPs in all the treatments had dropped to less than $80 \%$, ranging between 55 - 79\%, while all formulations of MaPs were completely ineffective with no larval mortality $15 \mathrm{~d}$ after introduction.

Table 5: Persistency of selected entomopathogenic fungal isolates in $200 \mathrm{~g}$ rice grains in plastic bags stored up to six months as indicated by mean percent larval mortality of Corcyra cephalonica 15 days after introduction

\begin{tabular}{clccccc}
\hline \multirow{2}{*}{ Fungi } & \multirow{2}{*}{ Carrier } & \multicolumn{5}{c}{ Duration of storage (months) } \\
\cline { 3 - 6 } & & 1 & 2 & 3 & 4 & 6 \\
\hline B. bassiana & Kaolin & $100 \mathrm{a}$ & $100 \mathrm{a}$ & $100 \mathrm{a}$ & $100 \mathrm{a}$ & $61 \mathrm{a}$ \\
(BbGc) & Talc & $100 \mathrm{a}$ & $100 \mathrm{a}$ & $100 \mathrm{a}$ & $96 \mathrm{bc}$ & $66 \mathrm{a}$ \\
& Tapioca Flour & $100 \mathrm{a}$ & $100 \mathrm{a}$ & $100 \mathrm{a}$ & $96 \mathrm{bc}$ & $67 \mathrm{a}$ \\
& Unformulated & $100 \mathrm{a}$ & $100 \mathrm{a}$ & $100 \mathrm{a}$ & $93 \mathrm{c}$ & $58 \mathrm{a}$ \\
\hline B.bassiana & Kaolin & $100 \mathrm{a}$ & $100 \mathrm{a}$ & $100 \mathrm{a}$ & $100 \mathrm{a}$ & $55 \mathrm{~b}$ \\
(BbPs) & Talc & $100 \mathrm{a}$ & $100 \mathrm{a}$ & $100 \mathrm{a}$ & $96 \mathrm{ab}$ & $62 \mathrm{~b}$ \\
& Tapioca Flour & $100 \mathrm{a}$ & $100 \mathrm{a}$ & $100 \mathrm{a}$ & $100 \mathrm{a}$ & $79 \mathrm{a}$ \\
& Unformulated & $100 \mathrm{a}$ & $100 \mathrm{a}$ & $100 \mathrm{a}$ & $95 \mathrm{~b}$ & $60 \mathrm{~b}$ \\
\hline M. anisopliae & Kaolin & $96 \mathrm{a}$ & $52 \mathrm{a}$ & $43 \mathrm{a}$ & $15 \mathrm{a}$ & $0 \mathrm{a}$ \\
& Talc & $92 \mathrm{ab}$ & $44 \mathrm{~b}$ & $42 \mathrm{a}$ & $20 \mathrm{a}$ & $0 \mathrm{a}$ \\
& Tapioca Flour & $88 \mathrm{~b}$ & $56 \mathrm{a}$ & $48 \mathrm{a}$ & $27 \mathrm{a}$ & $0 \mathrm{a}$ \\
& Unformulated & $66 \mathrm{c}$ & $35 \mathrm{c}$ & $26 \mathrm{~b}$ & $5 \mathrm{~b}$ & $0 \mathrm{a}$ \\
\hline
\end{tabular}

Means within column for each fungus followed by the same letter are not significantly different at $p=0.05$ according to least significant difference (LSD) 
The results presented indicated that the persistency of virulence for $B$. bassiana in dust formulations was longer than $M$. anisopliae when tested against $C$. cephalonica larvae. Beauveria bassiana seemed to sustain pathogenicity better than $M$. anisopliae in a drier environmental condition, and this concurs with the report by Hallsworth and Magan (1999). We conclude that the approach using air-dry conidia of $B$. bassiana in dust formulation is an effective microbial control tactic against C. cephalonica. Isolates Beauveria bassiana (BbGc and BbPs) provided good protection against C. cephalonica, inflicting in excess of $90 \%$ larval mortality $15 \mathrm{~d}$ after introduction. Protection was effective up to 4 months of storage at room temperature; the effectiveness began to decrease after 6 months of storage. However, the pathogenicity of $M$. anisopliae against $C$. cephalonica larvae decreased rapidly by the second month of storage at room temperature. Since this study was limited to carriers easily available in Malaysia, further experimentation involving other carriers are necessary for the optimisation of dust formulations. This includes studying the persistency of virulence upon storage in materials other than the plastic bag and realistic large-scale application of these formulations for the commercial scale.

\section{ACKNOWLEDGEMENTS}

The research was partially funded by the Integrated Pest Management for Smallholder Estate Crops Project-Plant Quarantine Component (ADB Loan No. 1469-INO). The resources made available by the Department of Plant Protection and the supports from the staffs are also gratefully acknowledged.

\section{REFERENCES}

1. Adane, K., Moore, D., and Archer, S.A. (1996), Preliminary studies on the use of Beauveria bassiana to control Sitophilus zeamais (Coleoptera: Curculionidae) in the Laboratory. Journal of Stored Product Reasearch, vol. 32, pp. 105-113.

2. Belloa, G.D., Padina, S., Lastrab, C.L., and Fabrizio, M. (2000), Laboratory evaluation of chemical biological control of rice weevil (Sitophilus oryzae L.) in store grain. Journal of Stored Product Reasearch, vol. 37, pp. 77-84.

3. Daoust, R.A., Ward, M.G., and Robert, D.W. (1983), Effect of formulation on the viability of Metarhizium anisopliae conidia. Journal of Invertebrate Pathology, vol. 41, pp.151-160.

4. Ekesi, S., Egwurube, E.A., Akpa, A.D., and Onu, I. (2001), Laboratory evaluation of the entomopathogenic fungus, Metarhizium anisopliae for the control of the groundnut bruchid, Caryedon serratus on groundnut. Journal of Stored Product Research, vol. 37, pp. 313-321.

5. EPA (2001), Protection of stratospheric ozone: process for exempting quarantine and preshipment application of methyl bromide. United States Environmental Protection Agency, Federal Register, vol. 66, pp. 37752-37769.

6. Finney, D.J. (1971), Probit analysis. Cambridge Univ. Press, Cambridge, UK.

7. Gomez, K.A. and Gomez, A.A. (1984), Statistical Procedures for Agricultural Research. John Wiley and Sons, Inc.

8. Hallsworth, J.E. and Magan, N. (1999), Water and Temperature Relations of Growth of the Entomogenous Fungi Beauveria bassiana, Metarhizium anisopliae and Paecilomyces farinosus. Journal of Invertebrate Pathology, vol. 74, pp. 261-266.

9. Hidalgo, E., Moore, D., and Patourel, G. LE. (1998), The effect of different formulation of Beauveria bassiana on Sitophilus zeamais in store maize. Journal of Stored Product Research, vol. 34, pp. 171-179. 
10. Hodges, R.J. (1979), A review of the biological and control of the rice moth Corcyra cephalonica Stainton (Lepidoptera: Gallerinae). Tropical Product Institute 56/26 Gray`s Inn Road, London.

11. Khan, A.R. and Selman, B.J. (1989), Nosema spp. (Microspora: Microsporida: Noesematidae) of stored product Coleoptera and their potential as microbial control agents. Agricultural Zoology Reviews, vol. 3, pp. 193-223.

12. Moy, J.H. (1988), Irradiation as a substitute to chemical fumigation of food. IAEATECDOC vol. 452, pp. 17-33.

13. Osman, N. and Nordin, N. (1990), Diet untuk pemeliharaan kupu-kupu beras, Corcyra cephalonica St. (Lepidoptera: Pyralidae). Pertanika, vol. 13, pp. 205-209.

14. Rice, W.C. (1999), Activity of the entomopathogenic fungus Beauveria bassiana (Deuteromycota: Hyphomycetes) against three coleopteran pest of stored grain. Journal of Economic Entomology, vol. 92, pp. 691-694.

15. Smith, S.M., Moore, D., Karanja, L., and Chandi, E.A. (1999), Formulation of vegetable fat pellets with pheromone and Beauveria bassiana to control the larger grain borer, Prostephanus truncatus (Horn.). Pesticide Science, vol. 55, pp. 711-718.

16. Tanya, S. and Doberski, J. (1984) An investigation of the entomogenous fungus Beauveria bassiana (Bals.) Vuill. as a potential biological control agent for Oryzaephilus surinamensis (L.). Journal of Stored Product Reasearch, vol. 20, pp. 17-23.

17. Ward, M.G. (1984), Formulation of Biological Insecticides. American Chemical Society. 